\title{
Does the Lagoa do Peixe sandbar opening influence the macrophyte richness and composition in Southern Brazil wetlands?
}

\author{
Ana Silvia Rolon ${ }^{1,2}$, Odete Rocha ${ }^{1} \&$ Leonardo Maltchik ${ }^{2 *}$ \\ 1. Federal University of São Carlos, São Carlos, Brazil; asrolon@gmail.com, doro@ufscar.br \\ 2. University of Vale do Rio dos Sinos, Ecology and Conservation of Aquatic Ecosystems, University of Vale do Rio dos \\ Sinos, UNISINOS. São Leopoldo, Rio Grande do Sul, Brazil, 93022-000; maltchik@unisinos.br \\ * Correspondence
}

Received 06-II-2012. Corrected 06-VIII-2012. Accepted 06-IX-2012.

\begin{abstract}
The Lagoa do Peixe has its connection with the sea artificially opened every year at the end of winter. However, this management has been carried out without the evaluation of the impact of this opening in the aquatic biodiversity. This information is crucial for the management of the natural resources of the Lagoa do Peixe National Park, the unique Ramsar site in Southern Brazil. The following questions were analyzed: (1) Do richness and composition of aquatic macrophytes from Lagoa do Peixe floodplain varies temporarily according to the sandbar opening and closing? (2) Does the variation pattern of the macrophyte community changed according to the sandbar opening and closing? A set of eight sampling sites of 1 ha were selected over the Lagoa do Peixe floodplain: four sites not influenced by the artificial sandbar opening and four sites influenced by this event, being two sites closer to the sandbar opening and the two sites distant to the sandbar opening. The samplings were carried out between November 2007 and October 2009. The results show that although the artificial sandbar breaching does not affect the aquatic macrophyte richness at the floodplain, it affects the dynamics of species composition. The hydrological variation related to this management can be the main factor of the continuous change in the species composition in the floodplain, especially in the Southern portion. In order to avoid impacts in the macrophyte conservation, the artificial sandbar opening should be considered carefully, since the area of study is one of the most important conservation units to wetland systems in Southern Brazil. Rev. Biol. Trop. 61 (1): 409-417. Epub 2013 March 01.
\end{abstract}

Key words: aquatic plants, floodplain wetlands, sandbar breaching, species composition stability.

Wetlands are ecosystems priority for conservation as they support high levels of biological productivity and diversity (Mitsch \& Gosselink 2000). Even so, great extension was already lost or had their ecological functions jeopardised (Shine \& Klemm 1999). Costal wetlands have been explored for centuries (e.g. fishing, cropping, urbanization and transportation) (Lotze et al. 2006), and in the last years, great land extensions have been urbanized (Kennish 2002). In the end of $20^{\text {th }}$ century, the global loss of coastal wetlands represented $1 \%$ per year (Hoozemans et al. 1993). Such rate could be even higher in some regions of Asia,
Africa and South America if the land use would be estimated (Kennish 2002).

Among several classes of coastal wetlands, lagoons present hydrological and geomorphological characteristics which influence the temporal dynamics of aquatic communities (Esteves et al. 2008). The lagoons are rare ecosystems and their connection to the sea (permanently or periodically) is due to rupture of sandy barriers that were formed by the tidal sediments deposition (Gönenç \& Wolflin 2004). By economic reason, their connection to the sea is managed in several parts of the globeSouth Africa (Bally 1987), Australia (Griffiths 
1999, Gladstone et al. 2006) and Brazil (Suzuki et al. 1998). However, the consequences of sandbar opening for the biodiversity have been little studied. Some studies pointed that changes in the water salinity and depth are the main factors related to modification in aquatic communities in managed wetlands (Suzuki et al. 1998, Santangelo et al. 2007).

Brazil presents one of the most extensive coasts in the globe - approximately $7500 \mathrm{~km}$ (Diegues 1999), however its disorderly occupation have caused several impacts resulting in habitat fragmentation and degradation and biodiversity loss (Diegues 1999, Esteves et al. 2008). In this sense, conservation actions driven to lagoons and their biodiversity have been considered priority in the Brazilian environmental policies (Barbosa et al. 2004, Esteves et al. 2008). Lagoa do Peixe National Park (LPNP) is one of the main wetlands conservation units in Southern Brazil. The LPNP protects several continental, estuarine and marine wetlands and a wide range of species belonging to several groups of organisms, including endangered species (Perello et al. 2010). The Lagoa do Peixe, an important lagoon located in the park, temporarily shelters 29 austral and boreal migratory bird species and it is considered the lagoon with high migratory birds diversity in Brazil (Nascimento 1995). The connection between Lagoa do Peixe and the sea has been artificially opened annually for the last 150 years due to economic interests of fishermen and cattle breeders (Saint-Hilaire 1987, Knak 2004). The artificial sandbar opening have been done to allow the entrance of shrimp (Farfantepenaeus paulensis) from the sea to the Lagoa do Peixe and to reduce the water level in its floodplain systems to increase the pasture area for the cattle. However, the impact of the sand bar opening on aquatic biodiversity is unknown. This information is crucial for the management of the natural resources of the Lagoa do Peixe National Park, the unique Ramsar site in Southern Brazil. In this sense, our study aimed to analyse the influence of artificial sandbar opening on macrophyte richness and composition in Lagoa do Peixe floodplains. Assuming that the hydrology of the floodplain is strongly associated with the opening and closing of the sandbar and that macrophyte richness and composition are intensely influenced by hydrological variations (Maltchik et al. 2007, Rolon et al. 2008), we raised the following questions: (1) Do richness and composition of aquatic macrophytes from Lagoa do Peixe floodplain vary temporarily according to the sandbar opening and closing? (2) Does the variation pattern of the macrophyte community vary according to the sandbar opening and closing?

\section{MATERIALS AND METHODS}

Study Area: The Coastal Plain of Rio Grande do Sul state is a region that presents high concentration of wetlands (Maltchik 2003) and high diversity of aquatic macrophytes (Irgang \& Gastal 1996). The study area is located in the Lagoa do Peixe National Park (Fig. 1). The park was established in 1986 and presented an area comprising 34 400ha, enclosing marine and freshwater environments (e.g. dunes, grasslands and restinga forest). Our study site was the Lagoa do Peixe floodplain. The floodplain of the Lagoa do Peixe is composed of a set of isolated ponds in a matrix of natural grassland. The soil saturation and hydrological condition of the ponds are influenced by rainfall and seasonal flooding of the Lagoa do Peixe that is the unique lagoon in Southern Brazil whose connection with the sea has seen managed by human activities. Due to this, there was no replicate to our sampling design. In this sense our study became a case study. The sandbar opening is carried out artificially in the end of the winter (August/ September) and the closing is done naturally by the actions of winds and tide between February and March. The sandbar opening has been done since before the creation of the park. This management is carried out by ICMBio - Instituto Chico Mendes de Conservação da Biodiversidade (Chico Mendes Institute for Biodiversity Conservation) and by the municipalities of Mostardas and Tavares. The sandbar 


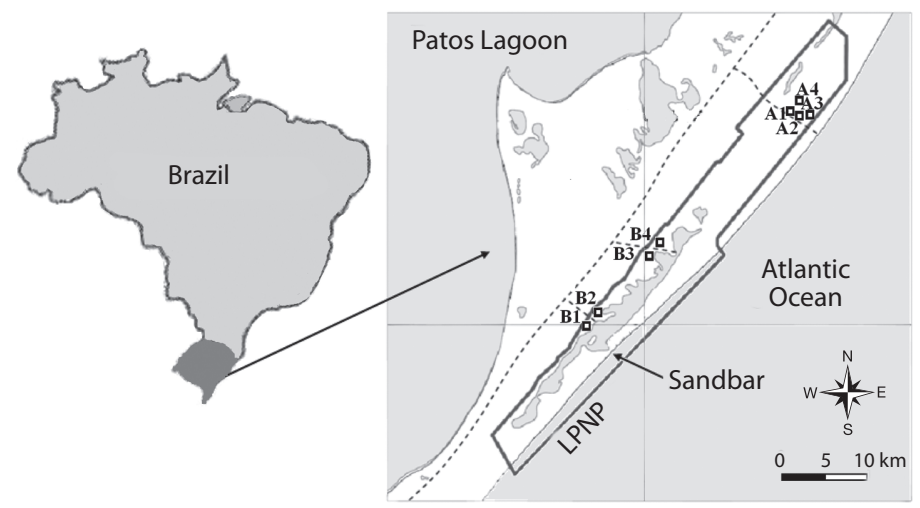

Fig. 1. Sampling sites localization in Lagoa do Peixe National Park (LPNP). Lagoa do Peixe floodplain areas without (A1 to A4) and with influence of sandbar opening (B1 to B4).

opening is done mechanically using a backhoe to dig a channel $200 \mathrm{~m}$ long, $40 \mathrm{~m}$ wide and $1.5 \mathrm{~m}$ deep; the process takes usually two days to be accomplished.

The local climate is humid subtropical with average annual temperature of $17.5^{\circ} \mathrm{C}$, varying from a mean of $13^{\circ} \mathrm{C}$ in the winter to $24^{\circ} \mathrm{C}$ in the summer. The average annual rainfall is $1500 \mathrm{~mm} /$ year (Tagliani 1995). The winds blow to Northeast $(5 \mathrm{~m} / \mathrm{s})$ from September to April and to Southwest $(8 \mathrm{~m} / \mathrm{s})$ from May to October (Klein 1998).

Sampling design: A set of eight sampling sites of tha were selected over the Lagoa do Peixe floodplain: four sites not influenced by the artificial sandbar opening distant $12 \mathrm{~km}$ from Lagoa do Peixe (A1-A4), and four sites in the Lagoa do Peixe floodplain influenced by this event (B1-B4) (Fig. 1). The sites B1 and $\mathrm{B} 2$ are closer to the sandbar opening and the sites B3 and B4 are more distant to the sandbar opening (located at the North extreme of Lagoa do Peixe) (Fig. 1). The minimum distance between the sampling sites was $0.5 \mathrm{~km}$ to increase the independence of the sampled areas.

Eight samplings were carried out between November 2007 and October 2009 over the different year seasons (Nov/07, Feb/08, May/08, Aug/08, Oct/08, Mar/09, Aug/09, Oct/09) comprising two artificial sandbar openings: four opened sandbar samplings and four closed sandbar (Table 1). The sampling period began in a year that the sandbar did not close. In 2008, the sandbar opening was on August $27^{\text {th }}$ and in 2009 on October $1^{\text {st }}$. The location of sampling sites was determined using GPS (Garmin, GPS III Plus). The variation of water salinity along the studied period was measured by a water quality checker (HORIBA U-22). The sampling sites were classified into four hydrological categories: 0 area without surface water; 1 - few ponds with surface water; 2 - many ponds with surface water; 3 - floodplain completely inundated by surface water.

Macrophyte richness was measured by visual search, which consisted in the qualitative analysis of the species present in the site (Convention on Biological Diversity 2003). Ten transects (three minutes) were sampled in each site (1ha). This amount 30 minutes of sampling at each sampling site. Each transect had its starting point randomized and they were sequentially distributed to the length of 25 meters $\left(50 \mathrm{~m}^{2}\right.$ area). Previous analysis indicated that a sampling effort of 30 minutes was sufficient to reach the total richness of study site (1ha of the floodplain; authors observation). We used the broad definition of aquatic macrophytes, which includes submerse, floating and emergent plants (herbs, shrubs and trees) and 
TABLE 1

Hydrological categories and mean salinity (parts per thousand) of sampling areas of Lagoa do Peixe floodplain (2007-2009). The sampling sites were classified in the following categories: 0 - area without surface water; 1 - area with few ponds with surface water; 2 - area with many ponds with surface water; 3 - floodplain completely inundated by surface water. Sampling sites: A1 to A4 - areas without influence of sandbar opening; B1 and

B2 - areas closer to the sandbar opening; B3 and B4 - areas more distant from the sandbar opening

\begin{tabular}{cccccccc} 
Period & Sandbar status & \multicolumn{3}{c}{ Hydrological categories } & \multicolumn{3}{c}{ Mean salinity (ppt) } \\
& & A1-A4 & B1-B2 & B3-B4 & A1-A4 & B1-B2 & B3-B4 \\
Nov/07 & Open & 2 & 2 & 2 & 0 & 0.12 & 0.15 \\
Feb/08 & Close & 2 & 0 & 1 & 0.06 & - & 0.03 \\
May/08 & Close & 2 & 1 & 2 & 0.04 & 0.22 & 0.08 \\
Aug/08 & Open & 2 & 2 & 3 & 0.02 & 0.05 & 1.45 \\
Oct/08 & Open & 2 & 1 & 2 & 0.02 & 0.44 & 0.10 \\
Mar/09 & Close & 2 & 1 & 2 & 0.05 & 0.70 & 0.10 \\
Aug/09 & Close & 2 & 2 & 3 & 0 & 0.10 & 0.10 \\
Oct/09 & Open & 2 & 2 & 2 & 0.02 & 2.05 & 0.60 \\
\hline
\end{tabular}

comprises a wide taxonomic variation (algae, bryophytes, pteridophytes and angiosperms).

The variation of species richness along two years in sites influenced and not influenced by the sandbar opening was tested using Repeated Measures ANOVA (SPSS 2002). The homogeneity of the variance was verified by the test of Levene and the sphericity -the proportionality between the covariance matrix and the identity matrix- was tested by the sphericity of Mauchy. Due to the absence of sphericity we applied the Greenhouse-Geisser correction for the F test (von Ende 1993).

We used the Detrended Correspondence Analysis (DCA) to assess the temporal variation of the species composition in the sites influenced and not influenced by the sandbar opening. The ordination analysis was carried out using the values of frequency of the species in the four sites subjected to the sandbar opening and in the other four ones not influenced by the opening in each sampling period $(n=8)$. The occurrence frequency varied from zero (absent) to four (present in all sites of the group). Posteriorly, we carried out a DCA for the four sites under influence of the sandbar opening. For this analysis, we considered the presence and absence of the species in each one of the sites along two years $(n=8)$.

A Permutational Multivariate Analysis of Variance (PERMANOVA) was used to compare differences in species composition between the sandbar opening and closing periods in the four sites under influence of the management. The Euclidian distance matrix was used to evaluate the difference in the composition among the sites and 9999 permutations to validate the model significance. The analyses were carried out using the vegan package (Oksanen et al. 2009) in the statistical software $\mathrm{R}$ version 2.9.0 (R Development Core Team 2009).

\section{RESULTS}

The salinity in areas closer to the sandbar opening (B1 and B2) varied from 0.05$2.05 \mathrm{ppt}$ over the studied period, it ranged from $0.03-1.45 \mathrm{ppt}$ in areas more distant from the sandbar opening (B3 and B4) and it varied from $0-0.06 \mathrm{ppt}$ in areas not influenced by the sandbar opening (A1-A4) (Table 1). The hydrologic condition in areas closer to the sandbar opening varied between 0-2 (Table 1) differently than those more distant from the sandbar opening that varied between 1-3 (Table 1). The variation of hydrologic condition was similar between B1 and B2, as well as B3 and B4. Constant hydrology (category 2) was observed in sampling sites not influenced by the sandbar opening (Table 1).

A total of 84 species of aquatic macrophytes was observed in the four sampling 
sites under the influence of sandbar opening, and 82 species were observed in four sampling sites without this influence (Appendix 1). Approximately $40 \%$ of the species observed in four sampling sites under the influence of the sandbar opening were found in all sampling periods, and $21 \%$ of species occurred only in one of the sampling periods. In the four areas not influenced by the sandbar opening, 49\% of the species were found during all sampling periods and $17 \%$ of species occurred only in one sampling period.

The total richness in wetlands under the influence of sandbar opening varied from 44 (May 2008) to 57 species (October 2008) along the studied period. The mean richness did not change over the time $\left(\mathrm{F}_{3.272,19.631}=1.164\right.$, $\mathrm{p}=0.351$; Fig. 2) and no interaction between time and type of wetland (whether influenced by the management or not) was observed in macrophyte richness $\left(\mathrm{F}_{3.272,9.631}=0.933\right.$, $\mathrm{p}=0.450$; Fig. 2).

The first two axes of ordination of wetlands influenced or not by the sandbar opening along the studied period explained $48.9 \%$ of the variation in macrophyte composition. The first axis explained $40.5 \%$ of variation and separated the sampling sites influenced by the sandbar opening from those not influenced
(Fig. 3). The second axis explained $8.4 \%$ of variation in the composition and delineated the species variation along two years (Fig. 3). While areas influenced by the sandbar opening were subjected to changes in species composition along the studied period, in areas not influenced by the sandbar opening the change in the species composition showed a cyclic

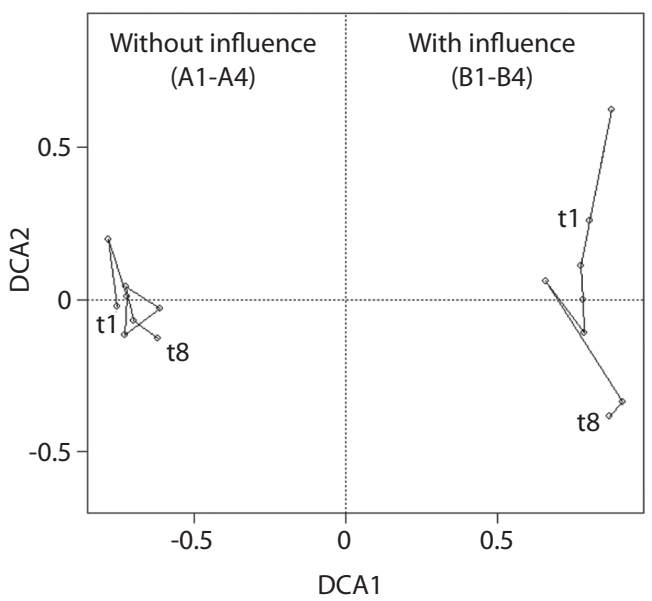

Fig. 3. Temporal ordination of aquatic macrophyte composition in floodplain areas with and without influence of the sandbar opening along the studied period (20072009). $\mathrm{t} 1=\mathrm{Nov} / 07$ (beginning of study), $\mathrm{t} 8=\mathrm{Oct} / 09$ (ending of study).

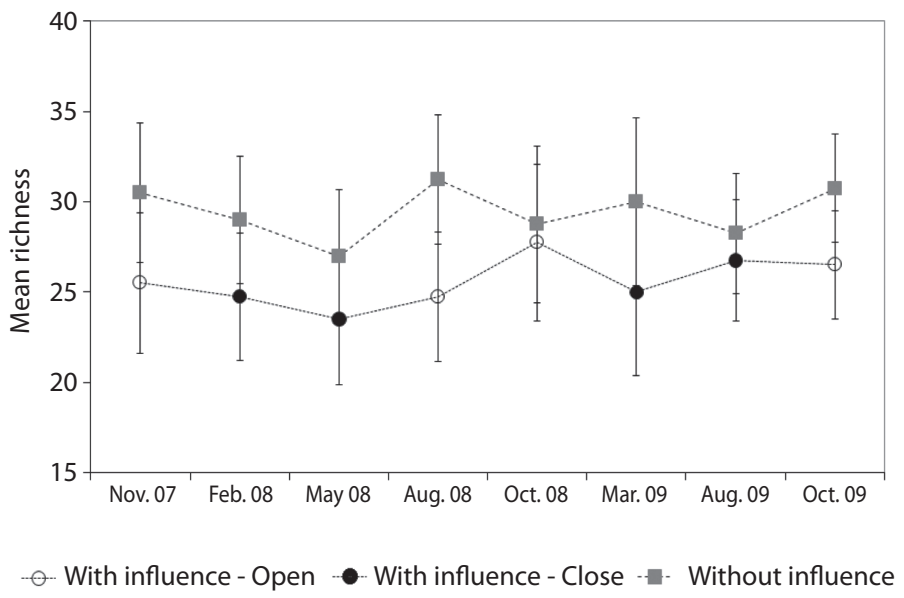

Fig. 2. Mean richness of macrophytes in floodplain areas with and without influence of the sandbar opening along the studied period (2007-2009). 
pattern (Fig. 3). The dispersion of the points indicated that the species replacement along the studied period was higher in areas influenced by the sandbar opening (Fig. 3).

The first two axes of ordination of the species composition in areas influenced by the sandbar opening explained $24.7 \%$ of variation in the species composition along two years. The first axis explained $15 \%$ and the second $9.7 \%$ of variation in the composition of aquatic macrophytes; these two axes separated the areas influenced by the sandbar opening (Fig. 4). Based on the dispersion of the points, we verified that the replacement of species in the two closest areas to the sandbar opening (B1 and B2) was superior to the others (Fig. 4). The change in species composition corresponded to a continuous pattern in wetlands close to the sandbar opening (B1 and B2) with little similarity between the first and the last sampling periods (Fig. 4). However, the macrophyte composition was similar among the periods before and after the sandbar opening $\left(\mathrm{F}_{1,6}=0.85979, \mathrm{p}<0.6279\right)$.

\section{DISCUSSION}

The connection between coastal lagoons and sea has been done artificially in many regions in the world to increase the fishing resources and to control flooding (Aguiaro \& Caramaschi 1995, Saad et al. 2002, Suzuki et al. 2002). Several studies carried out in lagoons observed the effects of sandbar opening on fish species composition (Griffiths 1999, Saad et al. 2002). However, the effect of this management practice on aquatic communities of lagoon floodplains is unknown. The sandbar opening of Lagoa do Peixe has been carried out over 150 years; however its effects on aquatic communities remain unknown.

Our results indicate that the plants richness did not vary over two years in the Lagoa do Peixe floodplain. The sandbar opening did not change the temporal dynamics of the macrophyte richness. The macrophytes dynamic was similar in areas with and without influence of sandbar opening. The percentage of constant species along two years was similar among

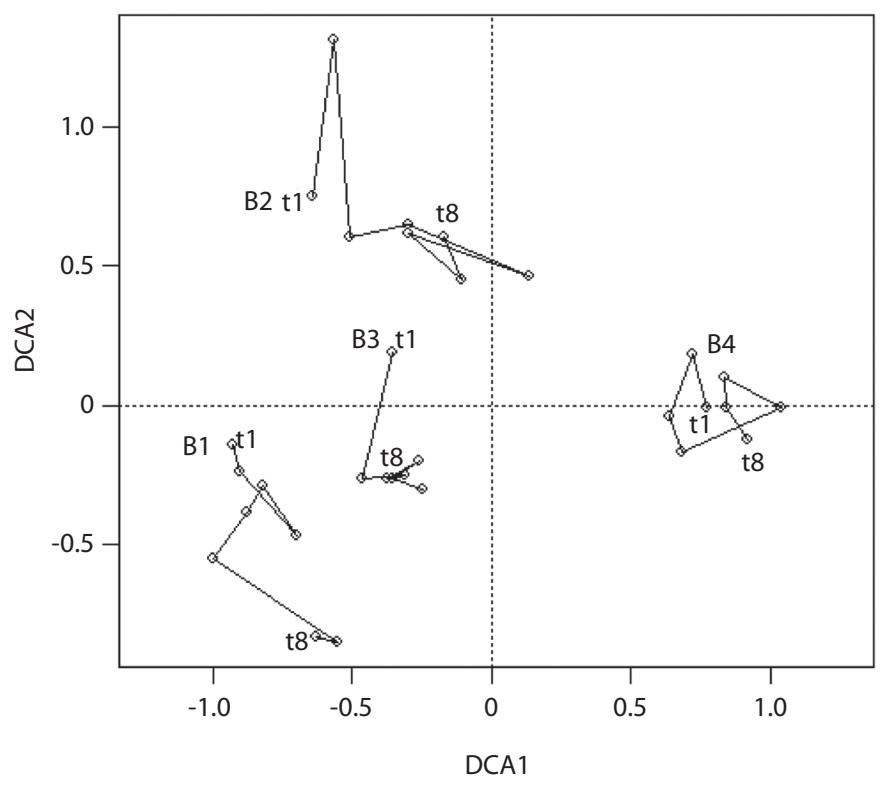

Fig. 4. Temporal ordination of aquatic macrophyte composition in the four floodplain areas with influence of the sandbar opening along the studied period (2007-2009). $\mathrm{t} 1=\mathrm{Nov} / 07$ (beginning of study), $\mathrm{t} 8=\mathrm{Oct} / 09$ (ending of study). The sites B1 and B2 are floodplain areas closer to the sandbar opening than sites B3 and B4. 
areas influenced and not influenced by the sandbar opening (40 and $49 \%$ of the species, respectively). The lack of variation in the macroinvertebrate richness before and after the sandbar opening was also observed in Australian estuaries (Gladstone et al. 2006). No similar results related to macrophytes were found in scientific literature.

Several studies emphasize the effect of salinity on macrophytes structure in wetland systems (Nielsen 2008). Although salinity varied from $0.03-2.05 \mathrm{ppt}$ in the floodplain, the macrophyte composition was characterized by species from freshwater environments, similar to other studies developed in palustrine and lacustrine systems in Southern Brazil (Rolon et al. 2010). Nevertheless, the temporal variation of macrophyte composition changed between treatments. While the change of macrophyte composition was more continuous along two years in areas influenced by the sandbar opening, the changes of macrophyte composition were more stable in areas not influenced by the sandbar opening. The response of the organisms to changes in the environmental conditions may vary from directional changes along time to abrupt fluctuations due to the loss of equilibrium (DeAngelis et al. 1985, DeAngelis $\&$ Waterhouse 1987). The macrophyte composition observed in areas not influenced by sandbar opening showed little variation along two years in areas not influenced by the sandbar opening and the species similarity was high among the eight sampling events. This result indicated that the composition of macrophytes was temporally stable in these study areas. On the other hand, the macrophyte composition presented a higher beta-diversity in areas influenced by the sandbar opening, presenting also a successional pattern in the variation of the species composition. This result suggests that the continuous replacement of macrophyte species along the studied period could be a response to the sandbar opening carried out each year at Lagoa do Peixe National Park. While emergent species were the main constant ones in areas influenced by the sandbar opening, the constant species of hydrophytes were associated to areas more distant from the influence of sandbar opening.

The successional pattern became more evident when we separately analysed the four areas under influence of sandbar opening. We observed a gradual change in macrophyte composition between the first and the last sampling event in areas near the sandbar opening. In areas more distant from the sandbar opening, we observed that the variation of macrophyte composition presented a more stable temporal pattern. Such difference may be related to variation in the hydrologic conditions of the four sampling sites. Variation of hydrologic condition may affect the establishment, growth and survival of aquatic plants (Blanch et al. 1999, Seabloom et al. 2001). The alternance of dry and flood periods influences the composition of aquatic macrophytes in Southern Brazil coastal wetlands (Schott et al. 2005, Maltchik et al. 2007). In areas distant from the sandbar opening, the presence of surface water was constant along the entire period, while in areas near the sandbar opening the reduction in the water availability in half of sampling periods (wetland without superficial water or less flooded) may have determined the lower stability of aquatic macrophytes.

Although the variation of aquatic macrophytes suggests an indirect effect of the sandbar opening, the composition did not differ between sandbar opening and closing periods. The lack of variation may be related to the high variation of macrophyte species composition within each one of the two periods studied. The high variation in macrophyte composition and the lack of differences among sandbar opening and closing periods has indicated the inexistence of a species composition associated with each one of the management periods.

Actions aiming at conservation of aquatic species in Southern Brazil wetlands are urgent, mainly where great part of these ecosystems are under intense degradation. Management practices without ecological research may cause several impacts in the species conservation, mainly in conservation units. The lack of other estuaries with similar management practices 
in Southern Brazil hindered the comparison of our results with other lagoons. However, results obtained from this study indicate that despite the sandbar opening do not change the macrophyte richness, the sandbar opening process affects the macrophyte composition. The hydrologic variation related to this management may be a factor responsible for the continuous change in the macrophyte composition. Facing such information, the artificial sandbar opening must be considered cautiously, since the area of study is one of the most important conservation units to wetland systems in Southern Brazil.

\section{ACKNOWLEDGMENTS}

We declare that the data collection complied with Brazilian current laws (IBAMA - 02001.001148/2007-61). This research was supported by funds from UNISINOS (02.00.023/00-0) and CNPq (52370695.2). Leonardo Maltchik holds a Brazilian Research Council-CNPq Research Productivity grant.

\section{RESUMEN}

La Lagoa do Peixe, en el sur de Brasil, tiene conexión artificial con el mar, porque cada año, al final del invierno, se abre un canal con tractor. Sin embargo, esta práctica se ha levado a cabo sin la evaluación de los efectos de esta apertura en la biodiversidad acuática. Las siguientes preguntas fueron analizadas: (1) ¿Varían la riqueza y la composición de los macrófitos acuáticos de la llanura de inundación temporal de la Lagoa do Peixe según la apertura y el cierre del banco arena? (2) ¿Varía el patrón de la comunidad de macrófitos según la apertura y el cierre del banco de arena? Los resultados muestran que la eliminación artificial del banco de arena no afecta la riqueza de macrófitos acuáticos en la llanura de inundación, pero sí afecta la dinámica de la composición de especies. La variación hidrológica relacionada con la apertura puede ser el factor principal del cambio continuo en la composición de especies en la llanura de inundación, especialmente en la parte sur. Con el fin de evitar un impacto negativo en la conservación de macrófitos, la apertura del banco de arena debe considerase cuidadosamente.

Palabras clave: plantas acuáticas, macrófitos, estabilidad de la composición, composición de especies, humedales de llanuras inundables, eliminación de bancos de arena.

\section{REFERENCES}

Aguiaro, T. \& E.P. Caramaschi. 1995. Ichthyofauna composition of three coastal lagoons in the north of the State of Rio de Janeiro (Brazil). Arq. Biol. Tecnol. 38: 1181-1189.

Bally, R. 1987. Conservation problems and management options in estuaries: the Bot River estuary, South Africa, as a case-history for management of closed estuaries. Environ. Conserv. 14: 45-51.

Barbosa, F.A.R., F.R. Scarano, M.G. Sabará \& F.A. Esteves. 2004. Brazilian LTER: Ecosystem and Biodiversity of Brazilian LTER. Environ. Monit. Assess. 90: 121-133.

Blanch, S.J., G.G. Ganf \& K.F. Walker. 1999. Tolerance of riverine plants to flooding and exposure by water regime. Regul. Rivers. Res. Manage. 15: 43-62.

Convention on Biological Diversity. 2003. Report of the expert meeting on methods and guidelines for the rapid assessment of biological diversity of inland water ecosystems. Eighth Meeting of the Conference of the Parties to the Convention on Biological Diversity, Montreal, Canadian. (Downloaded: September 10, 2009, http://www.biodiv.org/doc/meetings/sbstta/ sbstta-08/information/sbstta-08-inf-05-en.pdf.).

DeAngelis, D.L. \& J.C. Waterhouse. 1987. Equilibrium and nonequilibrium concepts in ecological models. Ecol. Monogr. 57: 1-21.

DeAngelis, D.L., J.C. Waterhouse, W.M. Post \& R.V. O'Neill. 1985. Ecological modelling and disturbance evaluation. Ecol. Model. 29: 399-419.

Diegues, A.C. 1999. Human populations and coastal wetlands: conservation and management in Brazil. Ocean. Coast. Manage. 42: 187-210.

Esteves, F.A., A. Caliman, J.M. Santangelo, R.D. Guariento, V.F. Farjalla \& R.L. Bozelli. 2008. Neotropical coastal lagoons: An appraisal of their biodiversity functioning, threats and conservation management. Braz. J. Biol. 68: 967-981.

Gladstone, W., N. Hacking \& V. Owen. 2006. Effects of artificial openings of intermittently opening estuaries on macroinvertebrate assemblages of the entrance barrier. Estuar. Coast. Shelf. Sci. 67: 708-720.

Gönenç, I.E. \& J.P. Wolflin. 2004. Coastal lagoons: ecosystem processes and modeling for sustainable use and development. CRC, New York, USA.

Griffiths, S.P. 1999. Consequences of artificially opening coastal lagoons on their fish assemblages. Int. J. Salt Lake Res. 8: 307-327.

Hoozemans, F.M.J., M. Marchand \& H.A. Pennekamp. 1993. A Global Vulnerability Analysis: Vulnerability Assessment for Population, Coastal Wetlands and Rice Production on a Global Scale. Delft Hydraulics, Delft, Netherlands. 
Irgang, B.E. \& C.V.S. Gastal Jr. 1996. Macrófitas Aquáticas da planície costeira do RS. CPG - Botânica/ UFRGS, Porto Alegre, Rio Grande do Sul, Brazil.

Kennish, M.J. 2002. Environmental threats and environmental future of estuaries. Environ. Conserv. 29: 78-107.

Klein, A.H.F. 1998. Clima regional, p. 5-7. In U. Seeliger, C. Odebrecht \& J.P. Castello (eds.). Os ecossistemas costeiro e marinho do extremo sul do Brasil. Ecoscentia, Rio Grande, Brazil.

Knak, R.B. 2004. Plano de manejo do Parque Nacional da Lagoa do Peixe. IBAMA/FNMA/FURG/NEMA/ UFPel, Portaria 012/2004, Brasília, Brazil.

Lotze, H.K., H.S. Lenihan, B.J. Bourque, R.H. Bradbury, R.G. Cooke, M.C. Kay, S.M. Kidewell, M.X. Kirby, C.H. Peterson \& J.B.C. Jackosn. 2006. Depletion, degradation, and recovery potential of estuaries and coastal seas. Science 312: 1806-1809.

Maltchik, L. 2003. Three new wetlands inventories in Brazil. Interciencia 28: 421-423.

Maltchik, L., A.S. Rolon \& P. Schott. 2007. Effects of hydrological variation on the aquatic plant community in a floodplain palustrine wetlands of Southern Brazil. Limnology 8: 23-28.

Mitsch, W.J. \& J.G. Gosselink. 2000. Wetlands. John Wiley \& Sons, New York, USA.

Nascimento, I.L.S. 1995. As aves do Parque Nacional da Lagoa do Peixe. IBAMA, Brasília, Brazil.

Nielsen, D.L. 2008. From fresh to saline: a comparison of zooplankton and plant communities developing under a gradient of salinity with communities developing under constant salinity levels. Mar. Freshw. Res. 59: 549-559.

Oksanen, J., R. Kindt, P. Legendre, B. O’Hara, G.L. Simpson, P. Solymos, M.H.H. Stevens \& H. Wagner. 2009. Vegan: Community Ecology Package. R package version $1.15-2$

Perello, L.F.C., D.L. Guadagnin, L. Maltchik, R.B. Menezes, A. Stranz \& J.E. Santos. 2010. Os desafios para a conservação do Parque Nacional da Lagoa do Peixe, RS, p. 135-151. In J.E. Santos, E.M. Zanin \& L.E. Moschini (eds.). Faces da Polissemia da Paisagem - Ecologia, Planejamento e Percepção. Rima, São Carlos, Brazil.

R Development Core Team. 2009. R: A language and environment for statistical computing. R Foundation for Statistical Computing, Vienna. Austria. ISBN 3-900051-07-0.
Rolon, A.S., H.F. Homem \& L. Maltchik. 2010. Aquatic macrophytes in natural and managed wetlands of Rio Grande do Sul State, Southern Brazil. Acta Limnol. 22: $133-146$.

Rolon, A.S., T. Lacerda, L. Maltchik \& D.L. Guadagnin. 2008. The influence of area, habitat and water chemistry on richness and composition of macrophyte assemblages in southern Brazil wetlands. J. Veg. Sci. 19: $221-228$

Saad, A.M., A.C. Beaumond \& E.P. Caramaschi. 2002. Effects of artificial canal openings on fish community structure of Imboassica coastal lagoon, Rio de Janeiro, Brazil. J. Coast. Res. 36: 634-639.

Saint-Hilaire, A. 1987. Viagem ao Rio Grande do Sul (1820-1821). Martins Livreiro, Porto Alegre, Brazil.

Santangelo, J.M., A.M. Rocha, R.L. Bozelli, L.S. Carneiro \& F.A. Esteves. 2007. Zooplankton responses to sandbar opening in a tropical eutrophic coastal lagoon. Estuar. Coast. Shelf Sci. 71: 657-668.

Schott, P., A.S. Rolon \& L. Maltchik. 2005. The dynamics of macrophytes in an oxbow lake of the Sinos River basin in south Brazil. Verh. Int. Ver. Theor. Angew. Limnol. 29: 815-820.

Seabloom, E.W., K.A. Maloney \& A.G. van der Valk. 2001. Constraints on the establishment of plants along a fluctuating water-depth gradient. Ecology 82: $2216-2232$.

Shine, C. \& C. Klemm. 1999. Wetlands, water and the law: Using law to advance wetland conservation and wise use. IUCN, Gland, Switzerland.

SPSS. 2002. Software package. SPSS. Statistical Package for Social Sciences, Chicago, USA.

Suzuki, M.S., R.O. Figueiredo, S.C. Castro, C.F. Silva, E.A. Pereira, J.A. Silva \& G.T. Aragon. 2002. Sand bar opening in a coastal lagoon (Iguipari) in the northern region of Rio de Janeiro state: hydrological and hydrochemical changes. Braz. J. Biol. 62: 51-62.

Suzuki, M.S., A.R.C. Ovalle \& E.A. Pereira. 1998. Effects of sand bar openings on some limnological variables in a hypertrophic tropical coastal lagoon, Brazil. Hydrobiologia 368: 111-122.

Tagliani, P.R.A. 1995. Estratégia de planificação ambiental para o sistema ecológico da Restinga da Lagoa dos Patos-Planície Costeira do Rio Grande do Sul. Ph.D. Thesis, São Carlos University, São Carlos, Brazil.

von Ende, C.N. 1993. Repeated-measures analysis: Growth and other time dependent measures, p. 113-137. In S. Scheiner \& I. Gurevitch (eds.). The Design and Analysis of Ecological Experiments. Chapman and Hall, New York, USA. 
